\title{
Feasibility of tomato production in aquaponic system using different substrates
}

\author{
M. A. Salam*, N. Jahan, S. Hashem and K. M. S. Rana \\ Department of Aquaculture, Faculty of Fisheries, Bangladesh Agricultural University \\ Mymensingh-2202, Bangladesh
}

\begin{abstract}
An aquaponics experiment was conducted to test the efficacy of different substrate such as gravel mixed with saw dust $\left(1: 1, \mathrm{~T}_{1}\right)$, only brick lets and gravels $\left(\mathrm{T}_{2}\right.$ and $\left.\mathrm{T}_{3}\right)$ for 116 days from 1 March to 25 June, 2013 at the roof of a building at Bangladesh Agricultural University (BAU) residential area with two replications to produce tomato in summer. Tilapia (mean initial length and weight were $6.18 \pm 0.92 \mathrm{~cm}$ and $5.85 \pm 2.30 \mathrm{~g}$, respectively) used as test animal at the rate of $134 \mathrm{fish} / \mathrm{m}^{3}$ water. The twenty days old healthy tomato seedlings were transplanted to the grow bed after stocking of tilapia. The waste water from the fish tank was irrigated using a 12 watt submersible pump to the vegetable beds and tank water was aerated with a 10 watt air pump fitted with two air stones. The irrigated water passed through the substrate where denitrifying and nitrifying bacteria converted nitrogenous compound to nitrites and then nitrates which then used by tomato plants as fertilizer and filtered water returned to the fish tank. Water quality, plant and fish growth were monitored fortnightly and detailed test was carried out three times in the lab. Evaporated and used up water was replaced with tap water daily. Data analysis showed that the water quality parameters were within the suitable range of fish culture. The mean length and weight of fish increased by $10.42 \pm 1.11 \mathrm{~cm}$ and $86.26 \pm 17.40 \mathrm{~g}$, respectively. The FCR for tilapia feed used in the present aquaponic system was 2.73 . Daily growth rate was $0.74 \%$ and the survival rate was $90 \%$. Total fish production was found 130 tons/ha/116 days. In case of tomato, the results showed that overall plants growth and weight of fruits was higher in $T_{3}$ than $T_{1}$ and $T_{2}$. Tomato production was 22.25, 37.74 and 87.41 tons/ha/116 days in $T_{1}, T_{2}$ and $T_{3}$, respectively. Thus, present results revealed that the gravels substrate gave the highest tomato production than the brick lets and gravels mixed with saw dust substrate
\end{abstract}

Key words: Aquaponics, substrate, bacteria, tilapia and tomato

Progressive Agriculturists. All rights reserved.

*Corresponding Author: masalambau@gmail.com

\section{Introduction}

Fisheries and aquaculture play a crucial role as a source of animal protein for billions of people worldwide and support the livelihoods of 10-12\% inhabitants in the world (FAO, 2012). In 2011, global aquaculture production was increased to 62.7 from 59 million tons in 2010 of which 89\% came from Asia. Demand for fish is leaping with the population increase in Bangladesh for the last three decades (FAO, 2012) which has increased the land use competition between agricultural crop production and fish farming (Ahmed and Garnett, 2011).
Moreover, land gets shrinking, reckless population growth, manmade environmental pollution and impact of climate change creates new challenges to the country's agriculture sector that has emphasized to integrate crop and fish farming like aquaponics (Salam et al., 2014). The word Aquaponics is the marriage of 'Aquaculture' and 'Hydroponics' and at the same time it shares some common attributes of both the systems, which is something far more developed and eventually, unique from either of them. Aquaponics is a typical urban agriculture, a 
combination of two different cultures: aquaculture or farming fish, and hydroponics or crop production in soilless substrate. It is the symbiotic relation between the fish and vegetables where fish provides fertilizer to the plants, in return plants help to purify the wastewater as they use the nutrients where the fish live in (Roe and Midmore, 2008). The aquaponics has control on farming systems which can protect the crops from diseases, heavy rains, floods, drought and hailstones. The aquaponics is an environmental friendly and sustainable food production system (Salam et al., 2013). Therefore, the present study was carried out to assess the production of Nile tilapia (Oreochromis niloticus) and tomato (Solanum lycopersicum) in aquaponic system, using different substrate keeping the water quality at an acceptable range for fish production.

\section{Materials and Methods}

The experiment was carried out for a period of 116 days from 1 March to 25 June, 2013 at the roof top of a four storied building at Bangladesh Agricultural University (BAU), Mymensingh. The roof is well protected from theft and kept locked always to prevent unwanted person to interfere the system. The experimental set up was in well exposed to sunlight.

\section{Experimental set up}

The aquaponics experimental system comprises of a 180 liter fish tank and six 22 liter capacity (44x35x14 $\mathrm{cm}^{3}$ ) food grain plastic containers for vegetable beds. The fish tank and vegetable containers were bought from local market and prepared for rearing of fish fingerlings and planting tomato saplings, respectively. Three types of substrate such as gravels of 1-3 mm sizes and saw dust mixed (1:1 in volume, $\mathrm{T}_{1}$ ), only brick lets of 2-5 cm sizes $\left(\mathrm{T}_{2}\right)$ and only gravels of 1-3 mm sizes ( $\left.T_{3}\right)$ were used (Fig. 1). The experiment was conducted with two replicates. The volume of the fish rearing tank was $0.35 \mathrm{~m}^{3}$. The tank was cut longitudinally to make an opening to facilitate the water exchange and fish feeding. Then the tank washed with tap water mixed with disinfectants and then sun dried. The pipes were plumbed to join the vegetable containers with the fish tank having an inlet and outlet of water. The tank bottom was filled with some gravels to provide natural habitat to the fish. These gravels were cleaned properly before placing in the tank. The tank water was aerated with a 10 watt air pump fitted with two air stones. The fish fingerlings of initial length$6.18 \pm 0.92 \mathrm{~cm}$ and weight-5.85 $\pm 2.30 \mathrm{~g}$ were purchased and acclimatized and realized in the tank at the density of 134 fingerlings per 1000 liter water. Simultaneously, 20 days old good quality tomato (Morning glory variety) saplings were procured and planted 4 saplings in each container. The fish was fed with commercial floating feed containing 30\% protein twice (at first feeding time 9:30 am and 4:00 $\mathrm{pm}$ ) daily at the rate of $5 \%$ body weight. The waste water was irrigated to the vegetable beds by a 12 watt submersible aquarium filter pump from 9:00 am to 5:00 pm (Irrigation Time) continuously which then returned passing through the substrate to the fish tank.

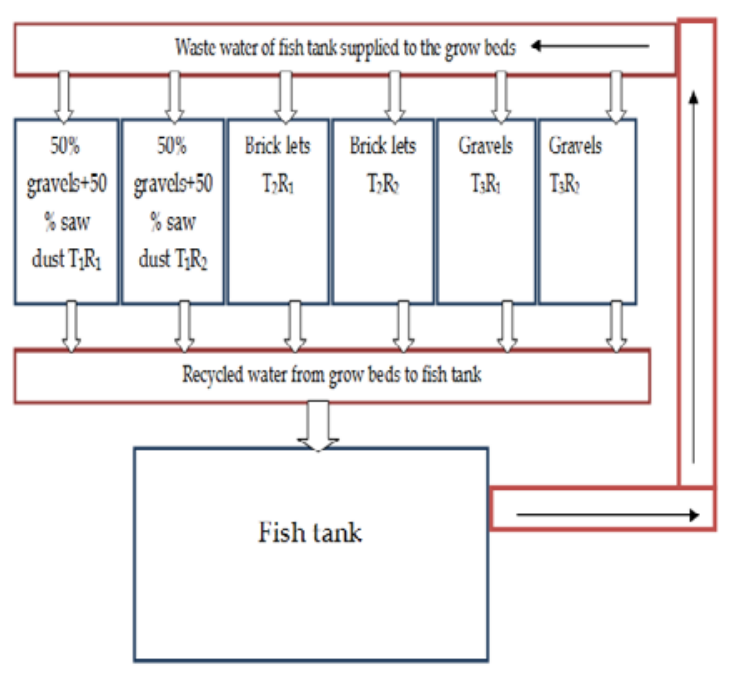

Figure 1. Schematic diagram of aquaponics system for growing fish and soilless vegetable

\section{Measurement of physico-chemical parameters of fish tank water}

The physico-chemical parameters of fish tank water were measured to know the water quality. Dissolved oxygen (DO), Temperature ( $\mathrm{T}$ ) and $\mathrm{pH}$ were measured every 15 days interval with portable equipments. On the other hand, total-nitrogen $(\mathrm{N})$, Electric conductivity (EC), Carbonate $\left(\mathrm{CO}_{3}\right), \mathrm{Bi}-$ carbonate $\left(\mathrm{HCO}_{3}\right)$, Potassium (K), Sulphur (S) and Sodium ( $\mathrm{Na}$ ) were measured monthly at the 
Humboldt Soil Testing Laboratory, Soil Science Department, BAU.

\section{Fish and vegetable sampling}

Fish and vegetable were sampled every 15 days interval. During each sampling, ten fishes were caught randomly with scoop net and individual length-weight was measured carefully with an electronic compact balance (KD-S/F-en) and wooden fish length measuring scale. After planting of tomato saplings the number of leaves was counted and height was measured at 15 days interval throughout the study period. The ripe tomato was weighed and recorded during harvesting.

\section{Fish and vegetable harvesting}

After 116 days of rearing the fish was harvested and their growth performance was measured such as length gain $(\mathrm{cm})$, weight gain (g), percent weight gain, food conversion ratio (FCR), survival rate (\%) and fish production $(\mathrm{kg} / \mathrm{ha})$. Ripen tomato was harvested and weighed until the experiment was completed. Following the plants death the roots were picked up from the beds and washed carefully with tap water. Both the roots and stems were dried and weighed by electric balance.

\section{Data processing and analysis}

Fish and tomato production, plant growth, water quality and nutrients removal was determined and expressed as mean \pm (standard deviation). Data analyses performed using Microsoft Excel 2007, with an alpha set at 0.05 and 0.01 (significance at $\mathrm{p}<0.05$ and $\mathrm{p}<0.01$ ). Mean values of fish production performances, crop growth rate, tomato yield, and nutrient removal tested with two-way ANOVA. If there were significant differences at significant level of 0.05 and 0.01 then Duncan Multiple Range Test (DMRT) was used to compare the means to show significant differences between the treatments.

\section{Results and Discussions}

\section{Water quality parameters}

The results of the water quality parameters were within the suitable range of fish culture throughout the experiment. The average $\mathrm{pH}, \mathrm{DO}$ and temperature values were $8.19 \pm 0.18,3.19 \pm 0.79 \mathrm{ppm}$ and $27.23 \pm 3.23^{\circ} \mathrm{C}$, respectively (Fig. 2). There was significant $(p<0.01)$ differences of temperature in different dates, however, no significant differences among the $\mathrm{pH}$ and DO values were found. It is reported that tilapia can survive at a $\mathrm{pH}$ range of 4 to 11 , but fish grow faster in water that is neutral or slightly alkaline (Shelton and Popma, 2006). In the present study the range of $\mathrm{pH}$ was 7.9 to 8.4 which is suitable for tilapia growth. In aquaponics system, Nitrosomonas and Nitrobacter need $\mathrm{pH}$ within 7.2 to 8.2, whereas nitrification is inhibited below the $\mathrm{pH}$ value of 5 (Villaverde et al., 1997). Therefore, the $\mathrm{pH}$ range in the present study was within the suitable range for nitrification.

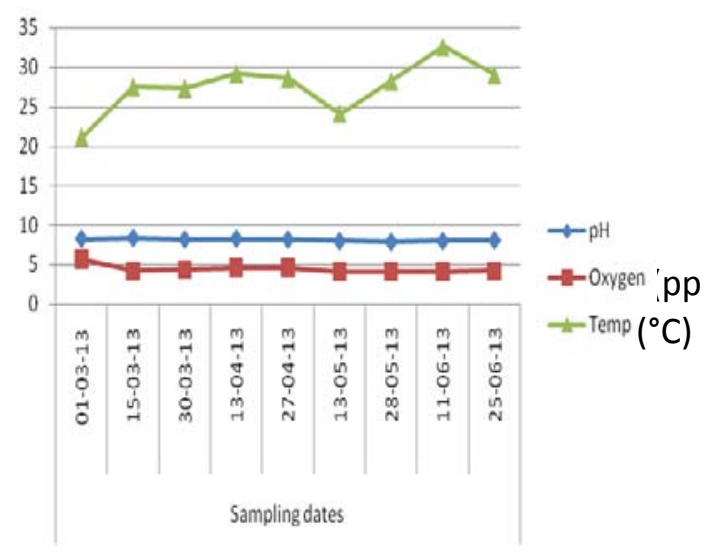

Figure 2. Variations of water quality parameters throughout the experimental period

Adequate aeration is essential in aquaponics system for proper growth and survival of the fishes. The DO concentration in the present study was found to vary from 4.07 to $5.69 \mathrm{ppm}$ which was within the suitable range of tilapia culture. The fish requires 5 ppm DO for optimal growth, and if the concentration falls below $2.5 \mathrm{ppm}$ the significant growth retardation occurred (Popma and Masser, 1999). In the present study, the DO concentration was decreased after 2 weeks from the starting of the experiment. This might be due to the microbial community and roots respiration. The nitrifying bacteria growing on the root systems could have contributed to oxygen uptake (Sutton et al., 2006). Tilapia has a high tolerance of temperature, with the optimal growth at $25-30^{\circ} \mathrm{C}$. Nitrifying bacteria can operate between 7 to $35^{\circ} \mathrm{C}$ temperatures with the optimum of $25^{\circ} \mathrm{C}$ (Wortman and Wheaton, 1991). During the 
experimental period the average water temperature was $27.23 \pm 3.23^{\circ} \mathrm{C}\left(21.1^{\circ} \mathrm{C}\right.$ to $\left.32.6^{\circ} \mathrm{C}\right)$ which has been reported as the optimum range for tilapia growth and yield (Meske, 1985).

\section{Water quality lab test}

The electric conductivity, bi-carbonate, total nitrogen and sodium content in the inlet water were highest $(791 \pm 0.71 \mu \mathrm{s} / \mathrm{cm}, \quad 564.25 \pm 4.3, \quad 4.2 \pm 1.98 \quad$ and $80.14 \pm 1.54 \mathrm{ppm})$ in April at the beginning of the experiment which was gradually decreased and reached to the lowest in June at the end of the experiment $(573 \pm 0 \mu \mathrm{s} / \mathrm{cm}, 219.6 \pm 8.63,11.2 \pm 0$ and $29.99 \pm 0.29)$ in the outlet water. These might happened as because at the beginning of the experiment there were not enough bacteria developed in the substrate and plant's required few. On the other hand, carbonate content in the system was nil throughout the experimental period. Moreover, phosphorous, potassium and sulfur content were the lowest at the beginning and gradually developed and reached at the highest concentration in May in the inlet water and then started to decrease gradually and continued at the end of the experiment. These were happened as the concentration was increasing slowly in fish tank and reached to the peak $(0.93 \pm 0.001$, $5.05 \pm 0.014$ and $5.26 \pm 0.13 \mathrm{ppm})$ in May and then started to decrease when plants started to consume and continued at the end of the experiment (Table 1). Similar result was obtained by Endut et al. (2009) with African catfish and water spinach production in aquaponics system. The lower nutrients concentrations are acceptable for aquaponics system because the nutrients are produced daily with the fish metabolic activities as well as mineralization of organic matter (Gurel and Yusuf, 2010; Rakocy et al., 2004).

Hong Xin et al. (2001) reported that the hydroponics vegetable production was maximum at $10.67 \%$ of total-nitrogen. In the present study after re-cycling, the lowest value of total-nitrogen was $3.5 \pm 0.99 \mathrm{ppm}$ found in outlet where in the inlet the value was $4.2 \pm 1.98 \mathrm{ppm}$, here $16 \%$ total-N was utilized by plants which was bit higher than the findings of Hong Xin et al. (2001).
In the outlet water the phosphorus $(\mathrm{P})$ concentration varied during the experimental period and it was in between 0.09-0.75 ppm. Boyd (1998) reported that the tolerable limit of $\mathrm{P}$ in aquaponics system was 0.20-1.15 ppm. In present study the phosphorous level was similar to Boyd study.

The highest value of total- $\mathrm{N}$ was found $16.35 \pm 0.64$ $\mathrm{ppm}$ in the inlet water; however, the value was $6.1 \pm 0.70 \mathrm{ppm}$ in outlet water in May. At the same time the concentration of potassium found in inlet $5.05 \pm 0.014$ and $4.26 \pm 0.012 \mathrm{ppm}$ in the outlet water. De Carmello and Anti (2006) found that tomato plants absorbed potassium in large concentrations followed by nitrogen while phosphorous was absorbed in the smaller amounts.

\section{Fish growth and production}

\section{Fish growth pattern}

Tilapia culture was started on 1 March and continued up to 25 June 2013, the experiment continued for 116 days. All the fishes were harvested on 25 June 2013. The initial mean length of the fish was $6.18 \pm 0.92 \mathrm{~cm}$ which increased to $16.60 \pm 1.18 \mathrm{~cm}$ and the mean weight was $5.85 \pm 2.30 \mathrm{~g}$ that increased to

$92.11 \pm 18.60 \mathrm{~g}$ during harvesting time. There was a significant $(\mathrm{p} \leq 0.01)$ difference in mean length and weight gain of fish among the different sampling dates.

The length and weight gain, percent weight gain and daily growth rate (g/day) were lower and food conversion ratio was bit higher in the present experiment than the findings of Endut et al. (2009) and Kamal (2006). The FCR for tilapia in the present experiment was bit higher (2.73) from the expected FCR for tilapia (1.5-2.0) (Watanabe et al., 2002). The survival rate (90\%) and production of fish (130 tons/ha/116 days) in the experiment was more or less similar with findings of Kamal (2006) and bit low from Endut et al. (2009) where the authors used African catfish (Table 2 and Fig 1).

Length-weight statistics of fish obtained for the experiment given along with the estimated lengthweight relationship and coefficient of determination $\left(\mathrm{r}^{2}\right)$ values was 0.95 in recirculating aquaponics system (Fig. 3 and Fig. 4). Conversely, the 
correlation coefficient (r) was 0.97 for tilapia in recirculating aquafonics system. The correlation coefficient in the experiment indicated that the length and weight of fish was strongly correlated and it was close to 1 , and its positive appearance reflected the positive slope. The condition factor of tilapia was 2.16 for tilapia. The condition factor $\mathrm{K}$ was higher than 1 in present experiment. Since the condition factor was larger than 1 , it concluded that fish reared in tank was in good condition as well as healthy. Mahomoud et al. (2011) and Nehemia (2012) calculated the condition factor for tilapia ranged between 1.66 to 2.02 and 1.64 to 2.13 which agree with the present aquaponics study.

Table 1. Water quality test results of tank and outlet water in different months

\begin{tabular}{|l|c|c|c|c|c|c|}
\hline \multirow{2}{*}{ Elements } & \multicolumn{2}{|c|}{ April-2013 } & \multicolumn{2}{c|}{ May-2013 } & \multicolumn{2}{c|}{ June-2013 } \\
\cline { 2 - 7 } & Inlet & Outlet & Inlet & Outlet & Inlet & outlet \\
\hline $\mathrm{EC}(\mu \mathrm{s} / \mathrm{cm})$ & $791 \pm 0.71$ & $762 \pm 1.41$ & $761 \pm 1.41$ & $737 \pm 1.41$ & $596 \pm 0.71$ & $573 \pm 0$ \\
\hline $\mathrm{CO}_{3}(\mathrm{ppm})$ & $\mathrm{Nil}$ & $\mathrm{Nil}$ & $\mathrm{Nil}$ & Nil & Nil & Nil \\
\hline $\mathrm{HCO}_{3}(\mathrm{ppm})$ & $564.25 \pm 4.3$ & $329.4 \pm 8.63$ & $259.25 \pm 4.31$ & $251.15 \pm 1.48$ & $234.85 \pm 4.32$ & $219.6 \pm 8.63$ \\
\hline Total-N(ppm) & $4.2 \pm 1.98$ & $3.5 \pm 0.99$ & $16.35 \pm 0.64$ & $6.1 \pm 0.70$ & $12.6 \pm 1.98$ & $11.2 \pm 0$ \\
\hline $\mathrm{P}(\mathrm{ppm})$ & $0.09 \pm 0.004$ & $0.23 \pm .004$ & $0.93 \pm 0.001$ & $0.53 \pm 0.002$ & $1.51 \pm 0.02$ & $0.75 \pm 0.01$ \\
\hline $\mathrm{K}(\mathrm{ppm})$ & $4.73 \pm 0.28$ & $3.65 \pm 0.13$ & $5.05 \pm 0.014$ & $4.26 \pm 0.01$ & $5.04 \pm 0$ & $4.54 \pm 0.14$ \\
\hline $\mathrm{S}(\mathrm{ppm})$ & $0.32 \pm 0.01$ & $0.23 \pm 0.02$ & $5.26 \pm 0.13$ & $3.45 \pm 0.33$ & $4.69 \pm 0.17$ & $3.54 \pm 0.17$ \\
\hline $\mathrm{Na}(\mathrm{ppm})$ & $80.14 \pm 1.54$ & $79.84 \pm 0.56$ & $35.54 \pm 0.02$ & $35.52 \pm 0.01$ & $29.99 \pm 0.29$ & $29.99 \pm 0.29$ \\
\hline
\end{tabular}

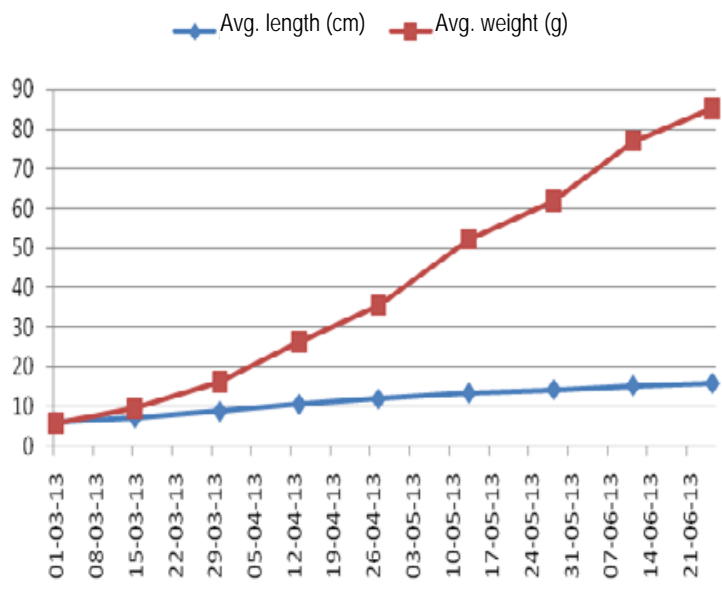

Sampling dates

Figure 3. Length and weight increment of the fish during culture period for 116 days

\section{Plant height, weight, root weight, no. of leaves and} tomato production

The highest mean height of the plant was $85.58 \pm 1.53$ $\mathrm{cm}$ found in $\mathrm{T}_{3}$ on 25 June. On the other hand, the plant heights were $60.38 \pm 8.31$ and $73.67 \pm 8.49 \mathrm{~cm}$ in $\mathrm{T}_{1}$ and $\mathrm{T}_{2}$, respectively. There were significant differences in mean heights of plants among the

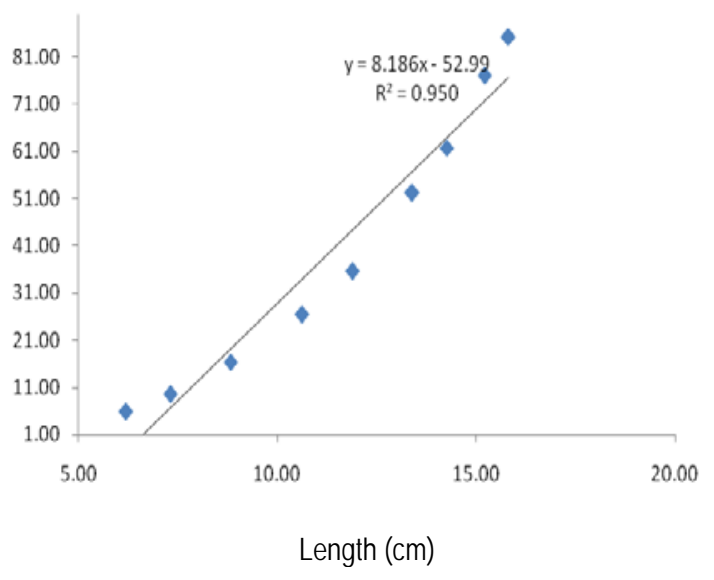

Figure. 4. Regression analysis of length and weight showed linear relationship for tilapia in recirculating aquaponics syste

treatments on 30 March, 13 and 27 April and 13 May (Fig. 5 and Table 3). Moreover, the highest mean number of leaves was $56.63 \pm 18.56$ in $\mathrm{T}_{3}$ on 13 May. At the same time the mean leaf numbers were 19.13 \pm 3.71 and 34.38 \pm 7.60 , respectively in $T_{1}$ and $\mathrm{T}_{2}$. The lowest numbers of leaf was $3.38 \pm 0.18$ found in $\mathrm{T}_{3}$ on 1 March (Fig. 5). There were significant differences in number of leaves in plants among the treatments. 
Table 2. Growth performances tilapia observed during the study period

\begin{tabular}{|l|c|}
\hline Growth performances & Value \\
\hline Mean initial length $(\mathrm{cm})$ & $6.18 \pm 0.92$ \\
\hline Mean final length $(\mathrm{cm})$ & $16.60 \pm 1.18$ \\
\hline Mean length gain $(\mathrm{cm})$ & $10.42 \pm 1.11$ \\
\hline \% length gain & $272.70 \pm 35.98$ \\
\hline Mean initial weight (g) & $5.85 \pm 2.30$ \\
\hline Mean final weight $(\mathrm{g})$ & $92.11 \pm 18.60$ \\
\hline Mean weight gain (g) & $86.26 \pm 17.40$ \\
\hline \% weight gain & $1754.3 \pm 1635.62$ \\
\hline Daily growth rate (g/day) & 0.76 \\
\hline Feed conversion ratio (FCR) & 2.73 \\
\hline Survival rate (\%) & 90 \\
\hline Production (tons/ha/116 days) & 130 \\
\hline
\end{tabular}

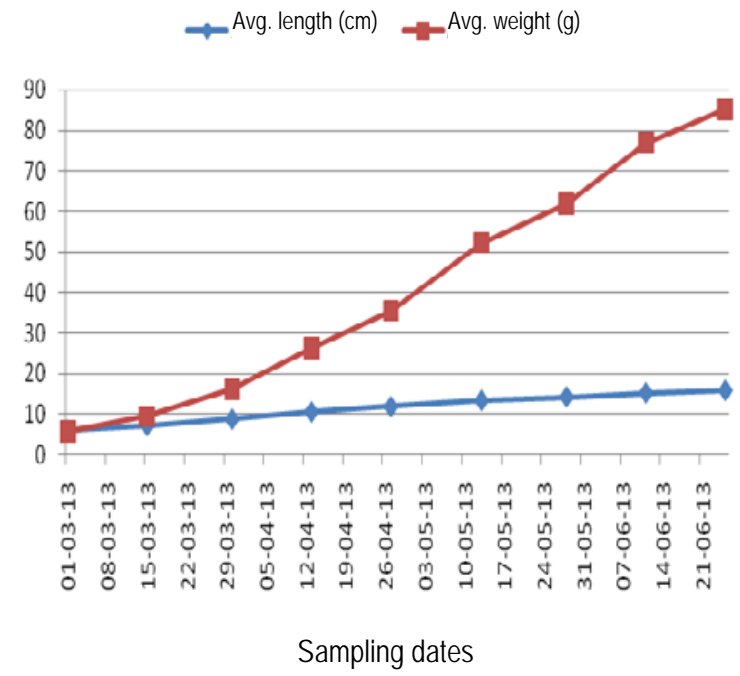

Figure 3. Length and weight increment of the fish during culture period for 116 days

The highest mean plant weights were $109.59 \pm 116.72$ $\mathrm{g}$ that was found in treatment $\mathrm{T}_{3}$ after harvest. On the other hand, plant weights were 59.66 \pm 22.81 and $108.88 \pm 69.14 \mathrm{~g}$, respectively in $\mathrm{T}_{1}$ and $\mathrm{T}_{2}$ (Fig. 6). Moreover, the highest mean root weights were $38.09 \pm 19.46, \quad 38.09 \pm 19.46$ and $23.77 \pm 23.33 \mathrm{~g}$, respectively in $T_{1}, T_{2}$ and $T_{3}$. The root weights of $T_{2}$ and $\mathrm{T}_{3}$ were statistically similar but dissimilar with $\mathrm{T}_{1}$. Tomato productions were significantly different $(\mathrm{p}<0.01)$ among the treatments (37.5, 40.0 and 88.33 tons/ha/116 days in $\mathrm{T}_{1}, \mathrm{~T}_{2}$ and $\mathrm{T}_{3}$, respectively) (Table 4, Fig. 6).

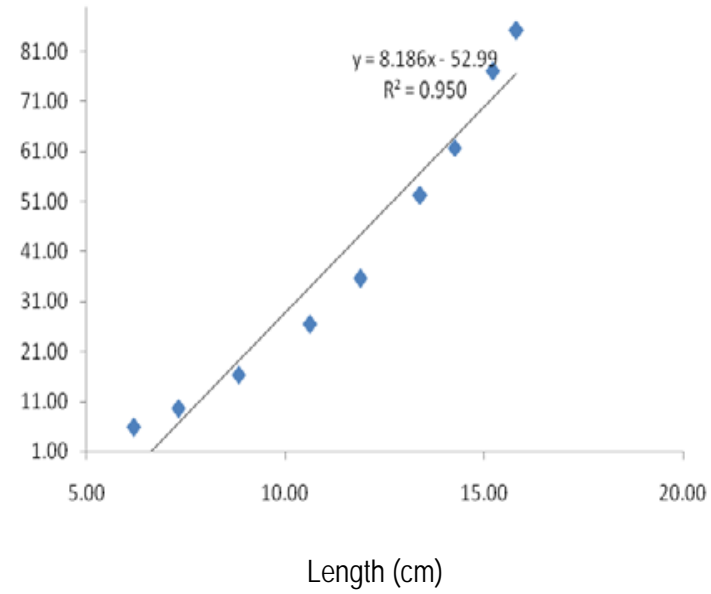

Figure. 4. Regression analysis of length and weight showed linear relationship for tilapia in recirculating aquaponics syste

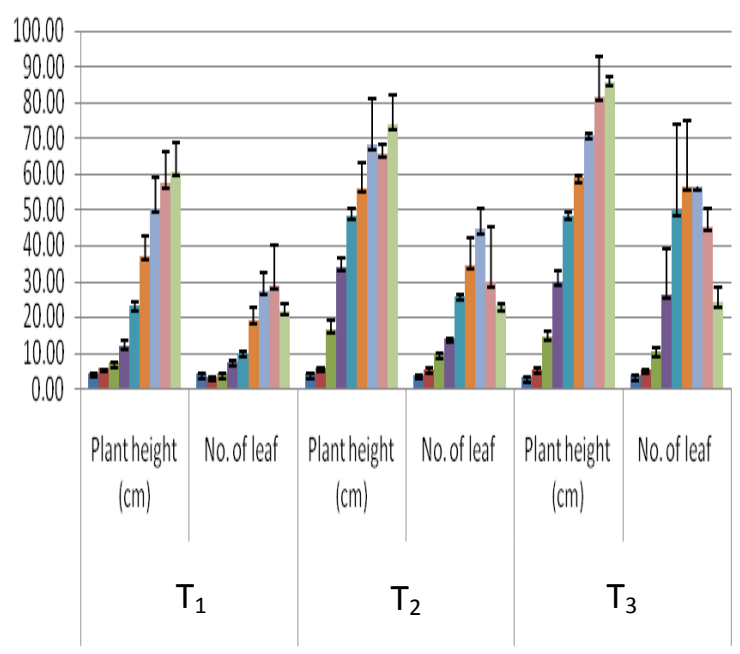

Figure 5. Plant height and number of leaves observed in three treatments over the study period

\section{IPlantweight Rootweight}

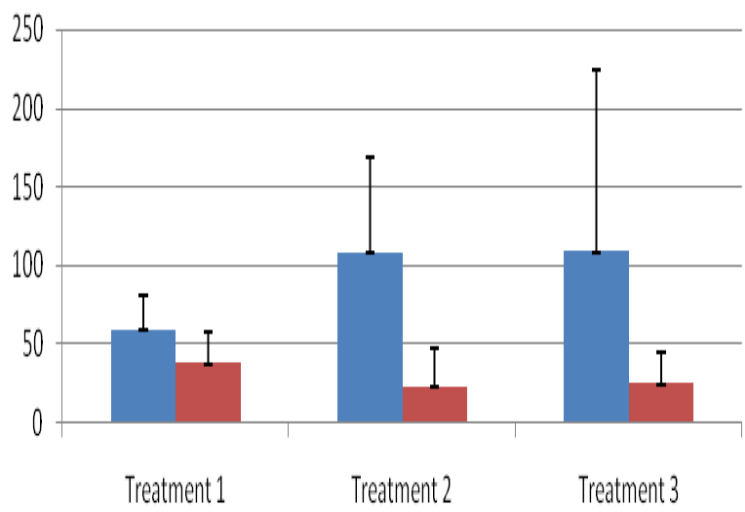

Figure 6. Plant weight and root weight gain by plants in $\mathrm{T}_{1}, \mathrm{~T}_{2}, \mathrm{~T}_{3}$ 
Table 3. Plant height observed in $\mathrm{T}_{1}, \mathrm{~T}_{2}$ and $\mathrm{T}_{3}$ during study period

\begin{tabular}{lcccc}
\hline $\begin{array}{c}\text { Date of } \\
\text { sampling }\end{array}$ & $\mathbf{T}_{\mathbf{1}}$ & $\mathbf{T}_{\mathbf{2}}$ & $\mathbf{T}_{\mathbf{3}}$ & $\begin{array}{c}\text { Level of } \\
\text { significance }\end{array}$ \\
\hline 01.03 .13 & $4.28 \pm 0.11$ & $3.94 \pm 0.62$ & $2.88 \pm 0.17$ & NS \\
15.03 .13 & $5.56 \pm 0.02$ & $5.73 \pm 0$ & $5.23 \pm 0.42$ & NS \\
30.03 .13 & $7.03 \pm 0.21$ & $16.53 \pm 2.58$ & $14.40 \pm 1.81$ & $*$ \\
13.04 .13 & $11.89 \pm 1.60$ & $34.06 \pm 2.56$ & $29.88 \pm 3.36$ & $* *$ \\
27.04 .13 & $22.95 \pm 1.52$ & $48.25 \pm 1.94$ & $48.31 \pm 0.97$ & $*$ \\
13.05 .13 & $37.0 \pm 5.48$ & $55.75 \pm 7.42$ & $58.81 \pm 0.97$ & NS \\
28.05 .13 & $50.5 \pm 8.48$ & $68.00 \pm 13.08$ & $70.63 \pm 0.89$ & NS \\
11.06 .13 & $57.28 \pm 9.10$ & $65.63 \pm 15.73$ & $81.79 \pm 2.18$ & NS \\
25.06 .13 & $60.38 \pm 8.31$ & $73.67 \pm 8.49$ & $85.58 \pm 1.53$ & \\
\hline
\end{tabular}

*Mean values are significantly different $(\mathrm{p}<0.05)$

$* *$ Mean values are significantly different $(\mathrm{p}<0.01)$

Leafy plants are best for trapping nitrogen from the wastewater, but its growth can be impaired if sufficient nitrogen is not available (Chen et al., 2004). Rakocy (1999) reported that the tomato growth was good enough in aquaponics system.

Aquaponics as an integrated system, it increases profit due to free nutrients, less water requirements, elimination of a separate bio-filter, less water quality monitoring, and crops and fish can be produced in the same space and time (Rakocy et al., 2004).

Total tomato productions in $\mathrm{T}_{1}, \mathrm{~T}_{2}$ and $\mathrm{T}_{3}$ treatments were 37.5, 40.0 and 88.33 tons/ha/116 days, respectively. Here, the tomato production from individual treatment was higher than the average yield (32.78 ton/ha/cycle) of summer tomato obtained by Karim et al. (2009). So, it can be concluded that aquaponics tomato production in summer is higher than production on land. The tomato production in $\mathrm{T}_{3}$ was $1.59 \mathrm{~kg}$ (or 88.33 tons/ha/116 days) whereas, $\mathrm{T}_{1}$ produced $0.68 \mathrm{~kg}$ (or 37.5 tons/ha/116 days) and $\mathrm{T}_{2}$ produced $0.72 \mathrm{~kg}$ (or 40.0 tons/ha/116 days). The substrate played major role in tomato production. A good substrate in aquaponic system maintains nutrients in the root zone and provides adequate space for gas exchange (Sikawa, 2010). The variations of tomato production were perhaps due to the effect of different bedding substrate. In $\mathrm{T}_{1}$, where gravels and saw dust (1:1) was used. During the experiment sometimes saw dust created water logged in the containers that made the substrate toxic and contaminated (e.g., antifungal chemicals used by the lumber industry). Saw dust composed of smaller grain size of wood; it may have inhibited proper drainage in aquaponic system. In $\mathrm{T}_{2}$, where brick lets were used as substrate, which may have affected the $\mathrm{pH}$ for plant growth as they are not $\mathrm{pH}$ neutral. Moreover, the water holding capacity of brick lets is not good for the plants. If water is not circulated continuously it may dry out the roots. By contrast, in treatment $T_{3}$ gravels were used as substrate, where large surface area available for bacteria to grow and perform nitrification. There were many pores and small holes in the substrate that provided the plant roots with air (McCauley et al., 2005).

\section{Conclusion}

The aquaponics system is increasingly used throughout the world for farming fish and vegetables in backyard and roof top and gaining popularity as it is profitable and environmental friendly. It is an innovative cropping system to grow both fish and vegetables. The major advantage of rearing high value crops such as fish and tomatoes using waste water from the fish tank which fertilize the plants continuously. At the same time, tomato beds are used as bio-filters to clean the waste water and recycled day after day, minimizing water use and cost. The horticulture-aquaculture enterprise recycles waste products and doubled the benefits.

Tilapia is known as "aquatic chicken" due to its adaptability to a wide range of environmental 
conditions, high growth rate and ability to grow and reproduce in captivity like aquaponics system and feed on low trophic level. As a result, the fish became an excellent candidate for recirculating aquafonics system, especially in tropical and subtropical regions. Indeed, tilapia became a versatile species for use in aquaponic system which is now practiced in most of the developed countries worldwide. The present experiment has proved that aquaponics system is suitable for fish and vegetable culture in high populated countries like Bangladesh for nutrient and food security.

\section{References}

Ahmed N, Garnett ST (2011). Integrated rice-fish farming in Bangladesh: meeting the challenges of food security. Food Sec., 3: 81-92.

Boyd CE (1998). Water Quality for Pond Aquaculture. International Center for Aquaculture and Aquatic Environments, Alabama Agricultural Experiment Station, Auburn University, Alabama. Research and Development Series No. 43.

Chen Q, Li X, Horlacher D, Liebig HP (2004). Effect of different nitrogen rates on open field vegetable growth and nitrogen utilization in the North China Plain. Comm. Soil Sci. Plant Anal., 35: 1725-1740.

De Carmello QAC, Anti GR (2006). Accumulation of Nutrients and Growth of Processing Tomato. 9th International Symposium on the Processing Tomato, Acta Hort., p. 38.

Endut A (2009). Effect of flow rate on water quality parameters and plant growth of water spinach (Ipomoea aquatica) in an aquaponics recirulating system. Desali. Water Treat., 5: 19-28.

FAO (2012). Food and Agricultural Organization of the United Nations, the State of World Fisheries and Aquaculture.

Gurel T, Yusuf G (2010). Aquaponic (Integrating Fish and Plant Culture) Systems. $2^{\text {nd }}$ International Symposium on Sustainable Development (ISSD), Sarajevo, Bosnia and Herzegovina, p. 657-666.
Hong XT, Guo ZL, Xue BZ, Yu JQ, Zhi MY, Hx T, GZ L (2001). Effect of hudroponic vegetable on water quality purification of aquaculture waste water. J. Shanghai Fish. Univ., 10: 293-297.

Kamal SM (2006). Aquaponic production of nile tilapia (Oreochromis niloticus) and bell pepper (capsicum annuuml.) In recirculating Water system. Egyptian J. Aqua. Biol. Fish., 10: 85-97.

Karim MR, Rahman MS, Alam MA (2009). Profitability of Summer BARI Hybrid Tomato Cultivation in Jessore District of Bangladesh. J. Agr. Rural Dev., 7: 73-79.

McCauley A, Jones C, Jacobsen J (2005). Basic Soil Properties. Montana State University Extension Service. pp. 1-12

Mahomoud WF, Amin AMM, Elboray KF, Ramadan AM, EL-Halfawy MMKO (2011). Reproductive biology and some observation on the age, growth, and management of Tilapia zilli (Gerv, 1848) from Lake Timsah, Egyptian Int. J. Fish. Aqua., 3: 1525.

Meske C (1985). Fish Aquaculture. Pergamon Press, Oxford, p. 55.

Nehemia A, Maganira JD, Rumisha C (2012). Length-Weight relationship and condition factor of tilapia species grown in marine and fresh water ponds. Agr. Biol. J. North America, 3:117-124.

Popma T, Masser M (1999). Tilapia life history and biology. Southern Regional Aquaculture Center. Publication No. 283: 310-318.

Rakocy JE (1999). Aquaculture engineering-the status of aquaponics. Part 1. Aqua. Mag., 25: 83-88.

Rakocy JE, Shultz RC, Bailey DS, Thoman ES, (2004). Aquaponic production of tilapia and basil comparing a batch and staggered cropping system. Acta Hort., 648: 63-69.

Roe BR, Midmore DJ (2008). Sustainable Aquaponics. Center for Plant and Water Science. CQ University, Rockhampton, Queensland, Australia. Pp. 78.

Salam MA, Asadujjaman M, Rahman MS (2013). Aquaponics for Improving High Density 
Fish Pond Water Quality through Raft and Rack Vegetable Production. World J. Fish Mar. Sci., 5: 251-256.

Salam MA, Hashem S, Asadujjaman M, Li F, (2014). Nutrient Recovery from in Fish Farming Wastewater: An Aquaponics System for Plant and Fish Integration. World J. Fish Mar. Sci., 6: 355-360.

Shelton W, Popma T (2006). Biology. In Lim, C. and Webster, C. (Eds). Tilapia Biology, Culture, and Nutrition. The Haworth Press, Inc., Binghamton, New York, pp. 4.

Sikawa DC, Yakupitiyage A (2010). The hydroponic production of lettuce (Lactuca sativa $\mathrm{L}$ ) by using hybrid catfish (Clariasmacrocephalus $\times$ C. gariepinus) pond water: Potentials and constraints. Agr. Water Man., 97: 13171325.
Sutton JC, Sopher CR, Owen-Going TN, Liu W, Grodzinski B, Hall JC, Benchimol RL, (2006). Etiology and epidemiology of Pythum root rot in hydroponic crops: Current knowledge and Perspectives. Summa Phytopathol., 32: 307-321.

Villaverde S, Garcia-Encina PA, Fdz-Polanco F, (1997). Influence of $\mathrm{pH}$ over nitrifying biofilm activity in submerged biofilters. Water Res., 31:1180-1186.

Watanabe WO, Losordo TM, Fitzsimmons K, Hanley F (2002). Tilapia production systems in the americas: technical advances, trends and challenges. Rev. Fish. Sci., 10: 465-498.

Wortman B, Wheaton F (1991). Temperature effects on biodrum nitrification. Aqua. Eng., 10: 183-205. 